\section{ANALISIS FAKTOR-FAKTOR YANG MEMPENGARUHI KEPUASAN KON- SUMEN BERBELANJA ONLINE DI PROVINSI PULAU JAWA}

\section{ANALYSIS OF FACTOR INFLUENCING CONSUMER SATISFACTION ONLINE SHOPPING IN THE PROVINCE OF JAVA}

Januar Israhmawan Putra ${ }^{1}$, Damayanti Octavia, SE., M.M²

Prodi S1 Manajemen Bisnis Telekomunikasi dan Informatika, Fakultas Ekonomi dan Bisnis, Universitas Telkom

ojanputra@students.telkomuniversity.ac.id, 리amavia@yahoo.co.id
JURNAL

MANAJEMEN

INDONESIA

Vol. 17 - No. 2

Agustus 2017

\title{
Abstrak
}

Penggunaan internet di Indonesia yang tumbuh dengan pesat diikuti dengan banyak bermunculan situs e-commerce yang merubah budaya dan gaya berbelanja masyarakat menjadi serba online. Pertumbuhan pasar e-commerce ini harus dibarengi dengan pelayanan yang akan diberikan kepada konsumennya secara baik agar konsumen merasa puas ketika bertransaksi kepada perusahaan. Tujuan penelitian ini yaitu untuk mengetahui faktor apa saja yang mempengaruhi kepuasan konsumen berbelanja online pada situs jual beli Lazada, Zalora, dan Mataharimall. Variabel independent yang digunakan dalam penelitian ini yaitu Website Design, Security, Information Quality, Payment Method, E-service Quality, Product Quality, Product Variety, Delivery Service dan variebel dependent adalah Customer Satisfaction. Responden dalam penelitian ini adalah konsumen Lazada, Zalora, dan Mataharimall yang berada di wilayah Provinsi Jawa Barat, Jawa Tengah, dan Jawa Timur dengan jumlah responden sebanyak 400 orang. Teknik sampling yang digunakan adalah nonprobability sampling yaitu porposive sampling. Penelitian ini menggunakan metode kuantitatif dengan teknik analisis data regresi berganda dan teknik analisis deskriptif. Hasil peneltian ini menunjukan bahwa website design, information quality, product vaiety, delivery service berpengaruh signifikan terhadap kepuasan konsumen dalam berbelanja online.

Kata kunci : website design, information quality, product vaiety, delivery service, security, product quality, e-service quality, payment method, customer satisfaction.

\section{Abstract}

The use of internet in Indonesia is growing rapidly. It is followed by the emergence of many e-commerce sites. Those sites change the shopping culture of Indonesian society by using the internet (online). The growth of e-commerce markets must be followed by the best service for the consumers. So, they will be satisfied after doing the transaction with the ecommerce markets. The aim of this study is to know the factors that affect the satisfaction of costumers in shopping by using e-commerce sites, such as Lazada, Zalora, and MatahariMall.. The independent variable used in this study is Website Design, Security, Information Quality, Payment Method, E-Service Quality, Product Quality, Product Variety, Delivery Service and dependent variebel is Customer Satisfaction. Respondents in this study are the consumers Lazada, Zalora, and Mataharimall located in the province of West Java, Central Java and East Java with the number of respondents as many as 400 people. The sampling technique used nonprobability sampling that is purposive sampling. This research used quantitative method with multiple regression data analysis techniques and descriptive analysis techniques. The results of this research shows that design website, information quality, product vaiety, delivery service has a significant effect on customer satisfaction in online shopping.

Keywords : website design, information quality, product vaiety, delivery service, security, product quality, e-service quality, payment method, customer satisfaction.

\section{Pendahuluan}

Indonesia adalah salah satu negara yang terkenal akan kepadatan penduduknya, kini Indonesia menduduki peringkat ke-4 sebagai negara dengan kepadatan penduduknya (Dickson, 


\section{JURNAL \\ MANAJEMEN \\ INDONESIA}

Vol. 17 - No. 2

Agustus 2017

Gambar 1.

Data Penggunaan dan Pertumbuhan Internet di Indonesia
2014). BPS (badan pusat statistika) yang memproyeksikan jumlah penduduk Indonesia ditahun 2015 sebesar 255462 atau sekitar 255 juta jiwa yang mengalami peningkatan dari tahun 2010 sebesar 238519 (Badan Pusat Statistik, 2014). Tingginya jumlah penduduk dapat dilihat sebagai suatu masalah bagi pemerintah, namun inilah yang menjadi peluang bagi perusahaan dengan banyaknya penduduk maka akan banyak pula konsumen yang akan datang pada perusahaan mereka. Kemajuan teknologi merupakan faktor tumbuhnya industri perusahaan di Indonesia.

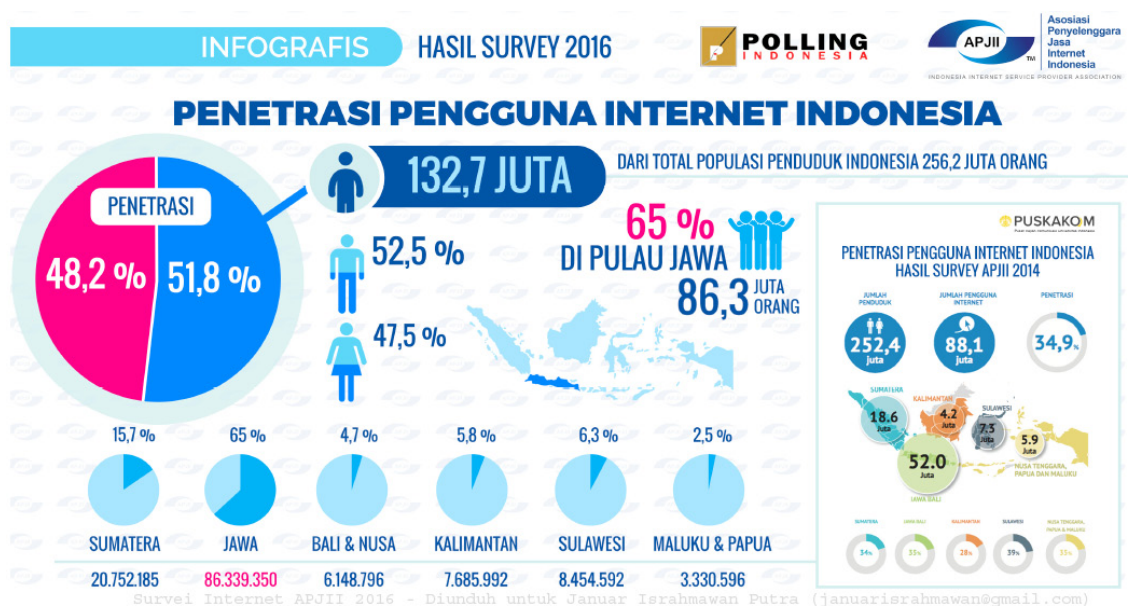

Internet menjadi salah satu faktor pendukung berkembangnya industri bisnis di Indonesia. Internet juga digunakan tidak hanya untuk kepentingan organisasi namun di Indonesia pertumbuhan akan internet yang digunakan oleh tiap individu terus meningkat jumlahnya dari tahun ke tahun. Dapat dilihat pada gambar 1 bahwa Pulau Jawa merupakan pengguna internet terbesar di Indonesia maka peneletian ini mengambil responden yang berada di $\mathrm{Pu}-$ lau Jawa.

Khusus e-commerce di Indonesia, market-nya diprediksi mencapai 52\% dari market e-commerce di Asia Tenggara menjelang tahun 2025, sementara pada tahun 2015 market Indonesia hanya berada di level $31 \%$. Fakta ini di dorong oleh tumbuh pesatnya kelas menengah sebagi user e-commerce, sedangkan akses ke retail (offline) makin tergerus. Market size e-commerce tumbuh 39\% per tahun dari 1,7 miliar dolar AS di tahun 2015 menjadi 46 miliar dolar AS pada 2025 (Majalah Mix Marketing Communication, 2016).

Business Monitor International (BMI Research) menyebutkan alasan seseorang untuk tidak berbelanja online, dari data yang didapat berdasarkan riset di tahun 2015 adalah 22\% pengguna merasa barang yang ada pada display tidak sesuai dengan barang yang diterima oleh pelanggan. Lamanya waktu pengiriman juga menyumbang sekitar 4\% alasan seseorang tidak berbelanja online, selain itu permasalahan koneksi juga masih menjadi masalah dari beberapa masyarakat untuk tidak berbelanja online, serta $5 \%$ responden juga masih enggan melakukan transaksi online karena merasa takut penipuan.Mengenai sistem pembayaran, BMI menyebutkan sekitar $82 \%$ pengguna belanja online melakukan transfer antar bank untuk menjadi media pembayaran. Sementara pembayaran lawas seperti Cash On Delivery (COD) masih digunakan oleh $20 \%$ pengguna belanja online, sekitar $5 \%$ pengguna menggunakan pay pal atau Kartu Kredit, dan sebagian kecil pengguna masih menggunakan rekening bersama (Rekber) (Apkomindo, 2014).

\section{Landasan Teori / Materi dan Metodologi / Perancangan}

\subsection{Perilaku Konsumen}

Perilaku konsumen adalah proses individu, kelompok, atau organisasi gunakan untuk memilih, menjamin, menggunakan, dan menentukan produk, jasa, pengalaman, atau ide untuk memuaskan kebutuhan dan mempengaruhi proses terhadap konsumen serta masyarakat (Hawkins et. al. 2013). 
Kepuasan pelanggan adalah perasaan senang atau kecewaan seseorang yang berasal dari perbandingan antara kesannya terhadap kinerja produk yang aktual dengan kinerja produk yang diharapkan (Sangadji \& Sopiah, 2013). Faktor utama penentu kepuasan pelanggan adalah presepsi pelanggan terhadap kualitas jasa (Lupiyoadi \& Hamdani, 2013).

\subsection{Faktor Yang Mempengaruhi Kepuasan Konsumen Berbelanja Online}

\section{A. Website Design}

Website desain adalah rancangan dari situs web yang dibuat agar mempermudah konsumen untuk melihat produk dan mudah untuk melakukan pembelian pada situs web suatu perusahaan (Laudon \& Traver, 2014). Desain website yang efektif mencakup kemampuan navigasi atau daya tarik visual dari website (Guo et. al. 2012).

\section{B. Security}

Kemanan dalam e-commerce adalah bagaimana informasi dari setiap konsumen dapat dijaga dan terbebas dari virus dalam situs web. Laudon dan Traver (2014) mendimensikan security menjadi 6 dimensi yaitu intregritas dimana informasi yang ada di dalam situs web belum diubah atau ditransmisikan oleh pihak yang tidak berkepentingan, nonrepudiation kemampuan untuk memastikan data dari setiap konsumen itu asli, keaslian kemampuan untuk mengetahui indentitas dengan siapakah konsumen bertransaksi, kerahasiaan kemampuan untuk memastikan bahwa tidak semua pesan dapat dilihat juga oleh setiap orang yang tidak berkepentingan, privasi kemampuan untuk mengolah data konsumen secara pribadi oleh konsumen itu sendiri dan bukan oleh orang lain, ketersediaan kemapuan untuk memastikan bahwa situs e-comerce berfungsi sebagaimana mestinya (Laudon \& Traver, 2014).

\section{Information Quality}

Information quality, informasi yang akurat kebenarannya karena dengan bertumbuhnya teknologi maka informasi bersifat mahal dan harus tepat dan ini termasuk dalam information density yaitu total kualitas informasi dalam suatu pasar (Laudon \& Traver, 2014).

\section{Payment Method}

Metode pembayaran yang ditawarkan dalam situs web diklasifikasikan menjadi lima yang pupuler sebagai moode pembayaran di e-commerce yaitu kartu kredit, PayPal, mobile ritel payment, Start-up, google wallet dengan sistem NFC nya. Riteler online biasanya menawarkan beberapa cara pembayaran, seperti pembayaran online menggunakan kartu kredit, pembayaran dengan uang tunai, dan telegraf remittance (Laudon \& Traver, 2014).

\section{E. E-Service Quality}

Merujuk pada e-servqual sejauh mana sebuah situs web memfasilitasi efisiensi dan efektifitas belanja, pembelian, dan pengiriman produk serta layanan (Guo et. al. 2012).

\section{F. Product Quality}

Kualitas produk adalah salah satu alat positioning utama pemasar. Kualitas mempengaruhi kinerja produk atau jasa; dengan demikian, itu berhubungan erat dengan nilai pelanggan dan kepuasan dan pemasar mengartikan kualitas sebagai nilai yang dibuat untuk konsumen dan untuk kepuasan (Kotler \& Amstrong, 2014).

\section{G. Product Variety}

Menawarkan berbagai macam produk merupakan kunci untuk pedagang web guna menjaga pelanggan datang kembali. Mengingat lebih banyak pilihan, akan ada kesempatan yang lebih tinggi untuk menjual produk. pengecer online yang telah menawarkan banyak berbagai produk dan pilihan tampaknya lebih sukses (Guo et. al. 2012). 


\section{H. Delivery Service}

\section{JURNAL}

MANAJEMEN

INDONESIA

\section{Vol. 17 - No. 2}

Agustus 2017

Gambar 2.

Kerangka Pemikiran
Pengiriman adalah jumlah waktu yang diperlukan untuk paket pergi dari pusat distribusi ke pelanggan (Guo et. al. 2012).

\subsection{Kerangka Pemikiran}

Gambar 2 menunjukan variabel-variabel yang digunaka dalam penelitian ini sebagai variabel Independent (x) yaitu Website Design, Security, Information Quality, Payment Method, E-service Quality, Product Quality, Product Variety, Delivery Service yag akan mempengaruhi variabel Dependent (y) yaitu Kepuasan Konsumen.

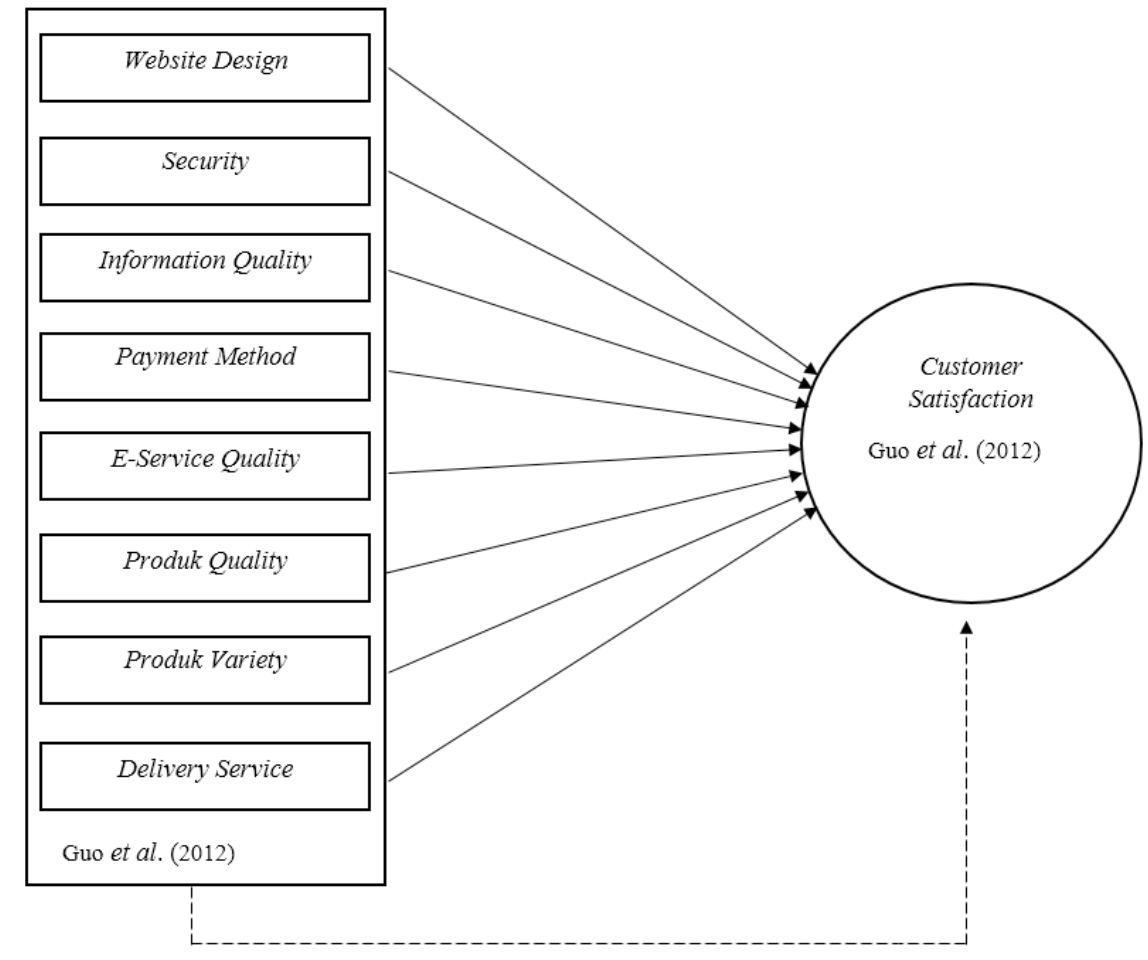

\subsection{Pertanyaan Penelitian}

1. Bagaimana tanggapan konsumen Lazada, Zalora, Mataharimall tentang website design, security, information quality, payment method, e-service quality, product quality, product variety, delivery service yang mempengaruhi kepuasan konsumen?

2. Bagaimana tanggapan responden mengenai kepuasan konsumen dalam berbelanja online di situs jual beli online Lazada, Zalora, Mataharimall di Provinsi Jawa Barat, Jawa Tengah, Jawa Timur?

3. Apakah Website Design berpengaruh signifikan terhadap kepuasan konsumen berbelanja online di Provinsi Pulau Jawa.

4. Apakah Security berpengaruh signifikan terhadap kepuasan konsumen berbelanja online di Provinsi Pulau Jawa.

5. Apakah Information Quality berpengaruh signifikan terhadap kepuasan konsumen berbelanja online di Provinsi Pulau Jawa.

6. Apakah Payment Method berpengaruh signifikan terhadap kepuasan konsumen berbelanja online di Provinsi Pulau Jawa.

7. Apakah E-Service Quality berpengaruh signifikan terhadap kepuasan konsumen 
8. Apakah Product Quality berpengaruh signifikan terhadap kepuasan konsumen berbelanja online di Provinsi Pulau Jawa.

9. Apakah Product Variety berpengaruh signifikan terhadap kepuasan konsumen berbelanja online di Provinsi Pulau Jawa.

10. Apakah Delivery Service berpengaruh signifikan terhadap kepuasan konsumen berbelanja online di Provinsi Pulau Jawa.

\subsection{Metode Penelitian}

Jenis Penelitian ini menggunakan metode analisi deskriptif. Data yang digunakan dalam penelitian ini adalah data primer yang diperoleh dari kuisioner yang disebarkan kepada 400 responden yang pernah bertransaksi di situs jual beli online Lazada, Zalora, dan Mataharimall serta berada di Provinsi Jawa Barat, Jawa Tengah, dan Jawa Timur. Teknik pengumpulan sampel yang digunakan adalah non-probability sampling yaitu purposive sampling. Metode kuntitatif dengan teknik analisis data yang digunakan adalah regresi linier berganda dan juga analisis deskriptif. Untuk menganalisis data tersebut dibantu dengan menggunakan SPSS.

\section{Pembahasan}

\subsection{Karateristik Responden}

Dalam penelitian ini responden enam point pertanyaan yang wajib diisi oleh responden untuk mengetahui karateristik dari responden dalam penelitian ini karateristik tersebut yaitu asal provinsi, jenis kelamin, umur, pendidikan terakhir, pekerjaan, dan pendapatan perbulan. Dalam penelitian ini responden didominasi oleh responden yang bertempat asal dari Provinsi Jawa Tengah sebanyak 158 orang lalu sisanya diisi oleh responden dari Provinsi Jawa Barat dan Jawa Timur. Sebanyak 200 orang adalah responden perempuan dan 200 lagi responden berjenis kelamin laki-laki. Umur 20-24 tahun menjadi reponden terbanyak dalam penelitian ini sebanyak 347 orang. Responden yang mempunyai pendidikan terakhir SMA sebanyak 229 orang serta memiliki pekerjaan terakhir sebagai pelajar/mahasiswa sebanyak 322 orang menjadi yang terbanyak dalam penelitian ini serta responden yang memiliki pendapatan perbulan sebesar Rp. 1.000.001 sampai dengan Rp. 2.000.000 menjadi reponden terbanyak dalam penelitian ini yaitu sebanyak 169 orang.

\subsection{Analisis Deskriptif}

Berikut adalah tabel yang menunjukan tanggapan responden tehadap variabel $\mathrm{x}$ dan $\mathrm{y}$ dalam penelitian ini.

\begin{tabular}{|c|c|c|c|}
\hline No & Variabel X & Presentase Rata-rata Skor & Kategori \\
\hline 1 & Website Design & $75,1 \%$ & Baik \\
\hline 2 & Security & $76 \%$ & Baik \\
\hline 3 & Information Quality & $76,2 \%$ & Baik \\
\hline 4 & Payment Method & $75 \%$ & Baik \\
\hline 5 & E-Service Quality & $78,40 \%$ & Baik \\
\hline 6 & Product Quality & $79,40 \%$ & Baik \\
\hline 7 & Product Variety & $78,50 \%$ & Baik \\
\hline 8 & Delivery Service & $79,30 \%$ & Baik \\
\hline \multicolumn{2}{|r|}{ Total } & \multicolumn{2}{|l|}{$617,9 \%$} \\
\hline & Presentase & $77 \%$ & Baik \\
\hline
\end{tabular}

Tabel 3.1 menunjukan hasil analisis deskriptif menurut tanggapan responden yaitu konsumen situs jual beli onliee Lazada, Zalora, Mataharimall yang ada di Pulau Jawa khusunya Jawa Barat, Jawa Tengah, Jawa Timur mengenai variabel (X) Website Design, Security, Information Quality, Payment Method, E-service Quality, Product Quality, Product Variety, 
Delivery Service menunjukan angka 77\% yang berarti bahwa ketiga perusahaan sudah melakukan hal tersebut dengan baik dan berarti baik juga dalam analisis deskriptif.

\section{JURNAL}

MANAJEMEN

INDONESIA

Vol. 17 - No. 2

Agustus 2017

Tabel 2

Tanggapan Responden

Terhadap Variabel ${ }_{\mathrm{Y}}$

\section{Tabel 3}

Hasil Analisis Regresi

Berganda dan Uji $t_{\text {test }}$

\begin{tabular}{|c|c|c|c|}
\hline No & Variabel Y & $\begin{array}{c}\text { Presentase Rata-rata } \\
\text { Skor }\end{array}$ & Kateogri \\
\hline 1 & $\begin{array}{c}\text { Customer satisfac- } \\
\text { tion }\end{array}$ & $78,6 \%$ & Baik \\
\hline
\end{tabular}

Tabel 3.2 menunjukan hasil analisis deskriptif menurut tanggapan responden mengenai variavbel (Y) kepuasan konsumen dalam analisis deskriptif juga berniali baik menurut konsumen situs jual beli online Lazada, Zalora, Mataharimall di Provinsi Jawa Barat, Jawa Tengah, Jawa Timur sebesar 78,5\% yang berarti bahwa responden sudah puas terhadap perusahaan.

\subsection{Analisis Regresi Linier Bergdanda dan Uji $t_{\text {test }}$}

Berikut adalah tabel yang menunjukan hasil dari analisis regresi berganda dan hasil dari uji t dalam penelitian ini yang dihitung dengan software SPSS.

\begin{tabular}{|c|c|c|c|c|c|}
\hline ents & $\begin{array}{l}\text { Standardized } \\
\text { Coefficients }\end{array}$ & & & Collineari & itistics \\
\hline ror & Beta & $t$ & Sig. & Tolerance & VIF \\
\hline ,740 & & 1,220 & .223 & & \\
\hline 031 & , 134 & 2,080 & .038 & , 298 & 3,361 \\
\hline 039 &, 005 & 101 & ,920 &, 586 & 1,705 \\
\hline ,038 & 127 & 2,675 & ,008 &, 549 & 1,820 \\
\hline 108 & ,006 & , 106 & ,915 &, 376 & 2,658 \\
\hline 053 & ,053 & 1,231 & .219 & ,674 & 1,483 \\
\hline , 078 & ,014 & ,309 &, 758 &, 640 & 1,563 \\
\hline , 047 & ,186 & 4,077 & ,000 &, 597 & 1,674 \\
\hline 052 &, 392 & 8,161 & , 000 & ,537 & 1,862 \\
\hline
\end{tabular}

a. Dependent Variable: y1 KepuasanKonsumen

Dari tabel 3.3 menunjukan angka angka yang akan digunakan dan dimasukan dalam persamaan sesuai dengan model persamaan regresi linier berganda.

Dalam penelitian juga dilakukan $\mathrm{jj}_{\mathrm{t}}$ atau $\mathrm{t}$ test untuk mengetahui pengaruh vari$\operatorname{abel}_{\mathrm{X}}$ terhadap variabel $\mathrm{Y}_{\mathrm{Y}}$ secara parsial dan menujukan hasil bahwa adanya 4 variabel $_{\mathrm{X}}$ yaitu website design $(0,038)$, information quality $(0,008)$, product variety $(0,000)$, dan delivery service $(0,000)$ yang masing masing memiliki nilai signifikansi kurang dari $(0,05)$ sebagai syarat bahwa variabel tersebut dikatakan berpengaruh signifikan. Dan variabel yang memiliki nilai pengaruh paling besar yaitu adalah variabel delivery service sebesar $(0,392)$ dalam data Standardized Coefficients, hal ini sejalan dengan penelitian yang dilakukan oleh Guo et al. (2012) yang mengatakan bahwa variabel delivery service mempunyai pengaruh paling kuat terhadap kepuasan konsumen berbelanja online. Sedangkan dalam penelitian ini variabel $_{\mathrm{x}}$ yang tidak mempunyai pengaruh terhadapah kepuasan konsumen berbelanja online adalah security $(0,920)$, payment method $(0,915)$, e-service quality $(0,219)$, dan product quality $(0,758)$ dimana variabel ini memiliki nilai signifikansi lebih besar dari $(0,05)$.

Kolom collinearity statistic menunjukan nilai VIF dimana nilai VIF variabel $_{\mathrm{x}}$ website design (3,361), security $(1,705)$, information quality $(1,820)$, payment method $(2,658)$, eservice quality $(1,483)$, product quality $(1,563)$, product variety $(1,674)$, dan delivery service

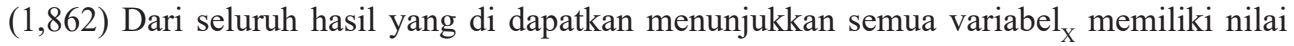
VIF kurang dari 10. Sehingga dapat disimpulkan bahwa seluruh variabel ${ }_{x}$ yang digunakan pada penelitian ini tidak terjadi multikolinearitas.

\subsection{Uji F (simultan)}

Berikut adalah tabel yang menunjukan hasil dari uji $\mathrm{F}$ dalam penelitian ini yang dihitung dengan software SPSS. 
ANOVA ${ }^{\mathrm{a}}$

\begin{tabular}{|rl|r|r|r|r|r|}
\hline Model & & \multicolumn{1}{c|}{$\begin{array}{c}\text { Sum of } \\
\text { Squares }\end{array}$} & df & Mean Square & \multicolumn{1}{c|}{ F } & Sig. \\
\hline 1 & Regression & 1573,550 & 8 & 196,694 & 51,863 &, $000^{\mathrm{b}}$ \\
& Residual & 1482,886 & 391 & 3,793 & & \\
& Total & 3056,436 & 399 & & & \\
\hline
\end{tabular}

a. Dependent Variable: y1 KepuasanKonsumen

b. Predictors: (Constant), x8DeliveryService, x5EServiceQuality, x4PaymentMethod x2Security, x6ProductQuality, x7ProuctVariety, x3InformationQuality, x1WebsiteDesign

Dari tabel 3.1 dapat dilihat hasil dari uji F dimana uji ini adalah untuk mengetahui pengaruh antara Website Design, Security, Information Quality, Payment Method, E-service Quality, Product Quality, Product Variety, Delivery Service dan Kepuasan Konsumen secara simultan atau secara bersama-sama. Uji F yang dilakukan menunjukan angka angka Fhitung ini sebesar 51,863. Nilai tersebut masuk sebagai syarat dikatakan sebuah variabel mempengaruhi secara simultan terhadap variabel lain karena nilainya melebihi nilai dari Ftabel $(2,236)$.

\subsection{Koefisien Determinasi ()}

Berikut adalah data yang menunjukan hasil pengolah uji $\mathrm{R}^{2}$ :

\section{Model Summary}

\begin{tabular}{|l|c|r|r|r|r|}
\hline Model & $R$ & R Square & \multicolumn{1}{|c|}{$\begin{array}{c}\text { Adjusted R } \\
\text { Square }\end{array}$} & $\begin{array}{l}\text { Std. Error of } \\
\text { the Estimate }\end{array}$ & $\begin{array}{l}\text { Durbin- } \\
\text { Watson }\end{array}$ \\
\hline 1 &, $718^{\mathrm{a}}$ &, 515 &, 505 & 1,94745 & 2,074 \\
\hline
\end{tabular}

a. Predictors: (Constant), x8DeliveryService, x5ESerrviceQuality, x4PaymentMethod, x2Security, $x 6$ ProductQuality, $x 7$ ProuctVariety, $x 3$ InformationQuality, $\mathrm{x} 1$ WebsiteDesign

b. Dependent Variable: y1KepuasanKonsumen

Tabel 3.3 menunjukan angka R Square sebsar 0.515 Hal ini menunjukan bahwa pengaruh variabel (X1) Website Design, (X2) Security, (X3) Information Quality, (X4) Payment Method, (X5) E-service Quality, (X6) Product Quality, (X7) Product Variety, (X8) Delivery Service terhadap Kepuasan Konsumen (Y) dalam model regresi sebesar 51,1\% sedangkan sisanya sebesar $48,9 \%$ dijelaskan oleh variabel lain yang tidak digunakan olehpeneliti.

\section{$4 \quad$ Kesimpulan dan Saran}

\subsection{Kesimpulan}

Berdasarkan analisis yang telah dilakukan, peneliti menemukan beberapa kesimpulan untuk menjawab pertanyaan penelitian ini. Berikut ini adalah kesimpulan yang dapat disimpulkan:

1. Tanggapan konsumen Lazada, Zalora, Mataharimall tentang website design, security, information quality, payment method, e-service quality, product quality, product variety, delivery service yang mempengaruhi kepuasan konsumen sudah termasuk dalam kategori baik.

2. Tanggapan responden mengenai kepuasan konsumen dalam berbelanja online di situs jual beli online Lazada, Zalora, Mataharimall di Provinsi Pulau Jawa sudah termasuk dalam kategori baik.

3. Website Design berpengaruh signifikan terhadap kepuasan konsumen situs jual beli online Lazada, Zalora, Mataharimall dalam berbelanja online di Provinsi Pulau Jawa.

4. Security tidak berpengaruh signifikan terhadap kepuasan konsumen situs jual beli
JURNAL

MANAJEMEN

INDONESIA

Vol. 17 - No. 2

Agustus 2017

Tabel 4

Hasil Pengolahan Uji F

Tabel 5

Hasil Uji R ${ }^{2}$ 


\section{JURNAL}

MANAJEMEN

INDONESIA

Vol. 17 - No. 2

Agustus 2017 online Lazada, Zalora, Mataharimall dalam berbelanja online di Provinsi Pulau Jawa.

5. Information Quality berpengaruh signifikan terhadap kepuasan konsumen situs jual beli online Lazada, Zalora, Mataharimall dalam berbelanja online di Provinsi Pulau Jawa.

6. Payment Method tidak berpengaruh signifikan terhadap kepuasan konsumen situs jual beli online Lazada, Zalora, Mataharimall dalam berbelanja online di Provinsi Pulau Jawa.

7. E-Service Quality tidak berpengaruh signifikan terhadap kepuasan konsumen situs jual beli online Lazada, Zalora, Mataharimall dalam berbelanja online di Provinsi Pulau Jawa.

8. Product Quality tidak berpengaruh signifikan terhadap kepuasan konsumen situs jual beli online Lazada, Zalora, Mataharimall dalam berbelanja online di Provinsi Pulau Jawa.

9. Product Variety berpengaruh signifikan terhadap kepuasan konsumen situs jual beli online Lazada, Zalora, Mataharimall dalam berbelanja online di Provinsi Pulau Jawa.

10. Delivery Service berpengaruh signifikan terhadap kepuasan konsumen situs jual beli online Lazada, Zalora, Mataharimall dalam berbelanja online di Provinsi Pulau Jawa.

\subsection{Saran}

Meskipun penelitian ini dapat memberikan wawasan baru bagi pembacanya namun perlu dilihat juga batasan dari penelitian ini. Batasan atau Kelemahan Penelitian ini adalah

1. Menggunkan data cross-section lalu saran untuk penelitian selanjutnya yaitu untuk menggunakan data Time Series dimana data ini dapat melihat pola dari suatu subjek dalam jangka waktu tertentu untuk mengetahui pengaruh dari kepuasan konsumen.

2. Responden terbatas pada Provinsi Jawa Barat, Jawa Tengah, Jawa Timur, saran untuk penelitian selanjutnya agar melakukan penelitiaan dengan rosponden lebih luas semisal responden untuk seluruh Provinsi yang ada di Pulau Jawa atau bahkan di Indonesia.

3. Dalam penelitian ini terdapat $48,9 \%$ variabel yang tidak ada dalam penelitian ini yang mempengaruhi kepuasan konsumen saran bagi penelitian selanjutnya adalah menggunkana variabel lain yang belum digunakan dalam penelitian ini seperti variabel experimental marketing dimana didalamnya terdapat sub-variabel seperti feel, act, sense, act, think, relate untuk mengetahui apakah variabel tersebut berpengaruh terhadap kepuasan konsumen dan juga dapat menghubungkan output kepuasan konsumen terhdap loyalitas konsumen dalam berbelnja online.

\section{Daftar Pustaka}

Dickson. 2014. 10 Negara Dengan Jumlah Penduduk Terbanyak di Duniahttp://ilmupengetahuanumum.com/10-negara-dengan-jumlah-penduduk-populasi-terbanyak-di-dunia/ [12 September 2016]

Badan Pusat Statistik. 2014. Proyeksi Penduduk Menurut Provinsi 2010-2035. https:// www.bps.go.id/linkTabelStatis/view/id/1274 [12 September 2016]

Majalah Mix Marketing Comunication.2016. Indonesia Best City Branding 2016.

Apkomindo. 2015. Pasar E-commerce Berpotensi Meningkat. [online]. http://www.apko- 
mindo.id/index.php/logo/item/96-2015-pasar-e-commerce-berpotensi-meningkat $\quad[12$ September 2016]

Hawkins, Del I dan Mothersbaugh, David L. 2013. Consumer Behavior. New York: Mc Graw Hill

Sangadji, Etta Mamang \& Sopiah. 2013. Perilaku Konsumen. Yogyakarta : Penerbit Andi

Lupiyoadi, Rambat dan A. Hamdani. 2013. Manajemen Pemasaran Jasa. Edisi Tiga. Jakarta: Salemba Empat

Laudon, Kenneth. C dan Traver, Carol Guerdo. 2014. E- Commerce, Business Technology Society USA: Addison Wesey

Guo et al. 2012. Evaluating Factors Influencing Consumer Satisfaction towards Online Shopping in China. Canadian Center of Science and Education

Kotler, Philip dan Amstrong, Garry. 2014. Principles Of Marketing, Global Edition.UK. Pearson
JURNAL

MANAJEMEN

INDONESIA

Vol. 17 - No. 2

Agustus 2017 